\title{
Effects of Generational Cohorts on Brand-Self Congruity, Emotional Brand Attachment, Perceived Investment, and Repurchase Behavior regarding Luxury Goods
}

\author{
Jihyun (J) Kim, Kent State University, USA \\ Hyun-Mee Joung, Northern Illinois University, USA
}

Key words: Luxury, attachment, congruity, investment

The global luxury market reached $€ 223$ billion in sales in 2014 (Bain \& Company, 2014). There are various factors surrounding the behavior of luxury consumption, such as emotional brand attachment, brand-self congruity, perceived investment, and repurchase intentions. First of all, creating emotional brand attachment is a key branding issue in today's marketing world. One way to accomplish this is to match the brand's personality with the consumer's self (i.e., selfcongruence) (Malär, Krohmer, Hoyer, \& Nyffenegger, 2011). Brand-self congruity refers to the perceived match between consumers' image of themselves and their image of a brand. A recent study reported that self-congruity positively predicted Australian consumers' attitude and loyalty toward the luxury brands for watches and sunglasses (Liu, Li, Mizerski, \& Soh, 2012).

Perceived investment is defined it as "consumer's overall perception of the degree of resources they have put into the relationship with their brands" (Sung \& Choi, 2012, p. 1056). They (2012) asserted that perceived investment should have multiple facets including financial, emotional, cognitive, behavioral, and time, based on the investment model. Last but not least, repurchase intention is a crucial part of the customer loyalty that predicts business success.

Different generations such as baby boomers (BB) and generation Y consumers exhibited varied shopping decision making as well as shopping patterns (Kincade, Kim, \& Gibson, 2010). In regards to the consumption of luxury goods, XXX (2015) examined the purchase frequencies of luxury goods among generational cohorts including silent generation, $\mathrm{BB}$, and generation $\mathrm{X}$ consumers. According to a recent White House report, the Millennials are the largest generation in the U.S. and holds substantial significance (The Council of Economic Advisors, 2014). Thus, this study investigated influences of generational cohorts - older BB, younger BB, generation X, and Millennials - on consumer trait variables introduced earlier and repurchase intentions of luxury goods among affluent US consumers to offer insights regarding the variances and/or similarities among the cohorts to the luxury marketing and retail industries.

In the present study, we employed a nationwide, representative sampling method using an online survey. The population of this study consisted of US affluent consumers whose annual household income of or greater than $\$ 150,000$ (Michman \& Mazze, 2006) using a panel of a marketing research firm. Among 788 responses, we screened out 312 responses which did not meet the criteria regarding income, luxury goods ownership or specification of luxury brands. The final sample size is 476 for data analysis. We adopted multi-item scales to measure the research constructs from the previous research mentioned above. Among our sample, females were $52.5 \%$. Most responses were from White $(81.9 \%)$, married (79\%), and annual household incomes ranged between $\$ 150,000$ and $\$ 299,999$ (75.6\%). Close to 45\% were BB (younger:

Page 1 of 2

( ) 2015, International Textile and Apparel Association, Inc. ALL RIGHTS RESERVED ITAA Proceedings, \#72 - www.itaaonline.org 
22.7\%; older: 22.3\%), followed by Generation Xers (24.2\%) and Millennials (23.9\%). Our participants were highly educated (Masters/Doctorate: 47.9\%; BA/BS: 33\%).

Multivariate Analysis of Variance revealed that there are statistically significant mean differences on all four variables - brand-self congruity, emotional attachment to luxury brand, perceived investment, and repurchase intention regarding luxury goods from the brand specified - among four generational cohorts $(F s>3.64 ; p s<.05)$. Post-hoc analyses using Scheffe test revealed that Millennials exhibited statistically a lower mean score on repurchase intention than did older $\mathrm{BB}(\Delta \mathrm{X}=-.44)$, yet showed a higher mean score on brand-self congruity than did older $\mathrm{BB}(\Delta \mathrm{X}=.55)$. Regarding emotional attachment to luxury brands (EALB), Millennials and Generation Xers exhibited substantially higher mean scores than older BB did $\left(\Delta \mathrm{X}_{\mathrm{EALB}}=.92 ; \Delta \mathrm{X}=.70\right.$, respectively $)$ and younger $\mathrm{BB}$ exhibited a significantly lower mean score on EALB, compared to Millennials $\left(\Delta X_{\text {EALB }}=-.64\right)$. Regarding perceived investment on luxury brand, there were statistically significant mean differences between older BB and Generation Xers $(\Delta X=-.58)$ and older BB and Millennials $\left(\Delta X_{P I}=-.90\right)$. In a similar pattern, younger BB exhibited significantly lower mean score on perceived investment on luxury brand than did Generation Xers $(\Delta X=-.56)$ and did Millennials $\left(\Delta X_{P I}=-.88\right)$. In general, Millennials showed their stronger EALB, self-congruity to the luxury brands, and perceived investment on luxury brands, except the repurchase intention. Generation Xers also exhibited similar patterns along with Millennials on EALB and perceived investment. These findings imply that younger consumers are more emotionally involved with the brand and believe that they have invested financially, emotionally, cognitively, behaviorally, and time-wise. Luxury marketing and retail industries certainly need to customize their strategies to cater to these markets that are highly invested in luxury goods. Future research may thoroughly examine the actual expenditure on the luxury brands and goods to corroborate the consumers' responses on the investment and their emotional attachment to predict their significance in the luxury marketplace.

Badrinarayanan, V., Becerra, E. P., \& Madhavaram, S. (2014). Influence of congruity in storeattribute dimensions and self-image on purchase intentions in online stores of multichannel retailers. Journal of Retailing and Consumer Service, 21, 1,013-1,020.

Liu, F., Li, J., Mizerski, D., \& Soh, H. (2012). Self-congruity, brand attitude, and brand loyalty: A study on luxury brands. European Journal of Marketing, 46(7/8), 922-937.

Malär, L., Krohmer, H., Hoyer, W. D., \& Nyffenegger, B. (2011). Emotional brand attachment and brand personality: The relative importance of the actual and ideal self. Journal of Marketing, 75(July), 35-52.

Michman, R. D., \& Mazze, E. M. (2006). The affluent consumer: Marketing and selling the luxury lifestyle. Westport, Connecticut: Praeger.

Sung, Y., \& Choi, S. (2010). "I won't leave you although you disappoint me": The interplay between satisfaction, investment, and alternatives in determining consumer brand relationship commitment. Psychology \& Marketing, 27(11), 1050-1073.

XXX. (In press). Impacts of U.S. affluent consumers' luxury consumption beliefs on repeat purchases of luxury goods: Generational and gender comparison analyses.

Page 2 of 2

(c) 2015, International Textile and Apparel Association, Inc. ALL RIGHTS RESERVED ITAA Proceedings, \#72 - www.itaaonline.org 